\title{
LOCAL MAPPING PROFILE OF MITOCHONDRIAL DNA (MTDNA)-LOOP IN FORENSIC IDENTIFICATION
}

\author{
Ahmad Yudianto ${ }^{1,2,3}$, Nola Margaret ${ }^{2}$ \\ ${ }^{1}$ Program for Master of Forensic Science, Post-Graduate School, ${ }^{2}$ Department of Forensic Medicine and Medicolegal, \\ Faculty of Medicine, ${ }^{3}$ Human Genetic study group, Tropical Disease Institute, Universitas Airlangga, Surabaya, \\ Indonesia
}

\section{ABSTRACT}

To prove that mitochondrial DNA damage is not total or partial, as has been found in the preliminary study, studies need to be done to determine the opportunity of successful use of the mitochondrial DNA mini-primer set in an amplicon product below $250 \mathrm{bp}$. This is important because it can overcome quality problems in degraded DNA, which will complicate the process of DNA forensic identification. This was an observational analytic study with cross sectional design. The study material was DNA from blood and sweat stains taken from abandoned bodies. Samples consisted of 24 pieces of blood and sweat spots. The measurements of mean DNA levels and sample purity used UV-Visible Spectrophotometer, revealing mean DNA in blood samples of $152.89 \pm 85.71 \mu \mathrm{g} / \mathrm{ml}$ and sweat samples of $89.19 \pm 5.58 \mu \mathrm{g} / \mathrm{ml}$, and sample purity of DNA and sweat were $1.89 \pm 0.71$ and $1.69 \pm 0.76$. Whereas, the result of D-Loop mtDNA: D-Loop I 143bp nt: 16268 -16410 and D-Loop HVS II 126bp nt: 34 -159, indicating blood spots were detected positively $>95 \%$ and sweat was detected positively in 5\%-20\%. Results of DNA sequencing from mtDNA of blood spots and sweat spots in $126 \mathrm{bp}$ and $143 \mathrm{bp}$ amplicon revealed nucleotide damage marked with the letter ' $N$ '. In conclusion, mini-primers of mitochondrial DNA in the amplification product mtDNA D-Loop HVS II 126 bp (nt 59-134) and D-Loop HVS I 143 bp (nt 1626816410) were effectively used as support for DNA profiling in forensic medicine.

Keywords: Mapping; mitochondrial DNA; forensic identification

\section{ABSTRAK}

Untuk membuktikan bahwa kerusakan DNA mitokondria tidak total atau parsial, seperti yang telah ditemukan dalam studi pendahuluan, perlu dilakukan penelitian untuk menentukan kemungkinan keberhasilan penggunaan set primer mini mitokondria DNA pada produk amplikon di bawah $250 \mathrm{bp}$. Hal ini penting dilakukan karena cara ini dapat mengatasi hambatan dengan kualitas DNA terdegradasi, yang akan mempersulit proses identifikasi forensik DNA. Jenis penelitian adalah observasional analitik dan desain penelitian cross sectional. Bahan penelitian adalah DNA dari noda darah dan noda keringat yang diambil dari jenazah terlantar. Sampel berupa setiap 24 potongan bercak darah dan bercak keringat. Pengukuran rata-rata tingkat DNA dan kemurnian sampel menggunakan Spektrofotometer UV-Visible dalam sampel darah $(152,89 \pm 85,71 \mu \mathrm{g} / \mathrm{ml})$ dan sampel keringat $(89,19 \pm 5,58$ $\mu \mathrm{g} / \mathrm{ml}$ ) serta kemurnian DNA sampel darah $(1,89 \pm 0,71)$ dan sampel keringat (1,69 $\pm 0,76)$. Sedangkan hasil visualisasi amplifikasi PCR daerah D-Loop mtDNA D-Loop HVS I 143bp nt: 16268 -16410 dan D-Loop HVS II 126bp nt: 34 -159 menunjukkan bintikbintik darah $>95 \%$ sampel yang terdeteksi positif $(+)$ dan keringat terdeteksi positif $(+) 5 \%-20 \%$. Hasil sekuensing DNA dari bercak darah dan keringat mtDNA produk bintik amplikon 126 bp dan 143 bp menunjukkan kerusakan nukleotida yang ditandai dengan huruf 'N'. Sebagai simpulan, mini-primer DNA mitokondria pada produk amplifikasi mtDNA HVS II D-Loop 126 bp (nt 59-134) dan HVS I D-Loop 143 bp (nt 16268-16410) secara efektif digunakan sebagai dukungan untuk profiling DNA di bidang kedokteran forensik.

Kata kunci: Pemetaan; DNA mitokondria; identifikasi forensik

Correspondence: Ahmad Yudianto, Department of Forensic Medicine and Medicolegal, Faculty of Medicine, Universitas Airlangga, Dr. Soetomo Hospital, Jalan Prof. Dr. Moestopo 6-8, Surabaya 60286, Indonesia. Email: yudi4n6sby@yahoo.co.id

pISSN:2355-8393 • eISSN: 2599-056x • http://dx.doi.org/10.20473/fmi.v54i3.10008

- Fol Med Indones. 2018;54:179-183 • Received 12 Oct $2017 \bullet$ Accepted 19 Apr 2018

- Open access under CC-BY-NC-SA license • Available at https://e-journal.unair.ac.id/FMI/ 


\section{INTRODUCTION}

In its development, examination using DNA material also has obstacles. One of the obstacles that become a serious problem, both for forensic DNA experts and others, is the degraded condition of the DNA. Basically, DNA testing with degraded DNA material is not much different in terms of its management. However, until now there has been no studies that reveal the use of mini primers set on DNA examination materials that are degraded due to exposure to extreme temperatures, such as that often found in cases of bomb explosions or fire. Burger (1999), for example, only studied or conducted microsatellite DNA studies in ancient skeletal remains, and so was the study by Chen et al (2000). Their study was limited on the effects of various environmental factors on (nuclea) DNA damage in dental pulp using for gender identification without identifying the patterns of DNA damage as a result of various environmental factors.

In fact, by identifying the performance of the mini primer set on material with degraded DNA, efforts of anticipatings steps in the DNA forensic examination, such as determining the right primer to be used in DNA testing on such materials, will be performed well. Thus, DNA typing for the purpose of DNA forensic identification in DNA degraded cases no longer becomes a crucial problem, so that forensic identification by using DNA typing will be performed in a relatively short time, even with a limited amount of DNA, which may happen because the victim's DNA has been damaged or degraded, resulting into fragmented DNA. Moreover, there has been a finding on the correlation between locus size and succesful amplification of degraded DNA obtained from crime scene or mass disaster (Brettell et al 2005). So far, the mapping of fragmented mtDNA loci in the forensic identification examination has not been widely known. The purpose of this study was to map the mtDNA loci that had been fragmented in forensic identification.

\section{MATERIALS AND METHODS}

This was an observational analytical study, conducted to map the DNA loci that can still be used in degraded DNA testing, using cross sectional design. The materials used were sweat and blood spots on fabric. For DNA extraction, the materials used were DNAzol Reagent, $100 \%$ solution and $70 \%$ ethanol. PCR Mix (12.5 ul) consisted of dNTP (ATP, CTP, TTP GTP), $\mathrm{MgCl} 2$ and Taq Polymerase, DW sigma (Nuclease Free water), mtDNA primary 143 bp (HVS I, nt 1626816410 ) (AFDIL, primer, Edson et al, 2004) 5 'CAC TAG GATACCAACAAACC 3' \& 5 'GAGGATGGT
CAA GGGAC 3', mtDNA 126 bp (HVS II, nt 34-159) (AFDIL, primer, Gabriel et al 2001) 5 'GGG AGC TCT CCA TGC ATT TGG TA 3' \& 5 'AAA TAA TAG GAT GAG GCA ATC 3'.

\section{RESULTS}

Levels and purity of DNA samples (blood and sweat spots)

Table 1. Mean levels and purity of DNA of blood and sweat spots

\begin{tabular}{ccc}
\hline Samples & $\begin{array}{c}\text { Mean DNA levels } \\
(\mathrm{x} \pm \mathrm{SD})(\mu \mathrm{g} / \mathrm{ml})\end{array}$ & $\begin{array}{c}\text { Mean DNA purity } \\
(\lambda 260 \mathrm{~nm} / \lambda 280 \mathrm{~nm})\end{array}$ \\
\hline Blood spot & $152.89 \pm 85.71$ & $1.89 \pm 0.71$ \\
Sweat spot & $89.19 \pm 5.58$ & $1.69 \pm 0.76$ \\
\hline \multicolumn{2}{l}{ Note: X: mean DNA content, SD: Standard Deviation }
\end{tabular}

Table 1 shows the extraction and isolation of DNA samples from blood and sweat spots in which mean level and purity are qualified for PCR amplification. Minimum level was $0.5 \mathrm{ng}$ and the purity was between $1-8$.

\section{Amplification of DNA sample PCR}

PCR process used primers in the hypervariable region (D-Loop HVS II 126 bp (nt 59-134) and D-Loop HVS I $143 \mathrm{bp}$ (nt 16268-16410). The following are PCR visualization results through $2 \%$ agarose gel.

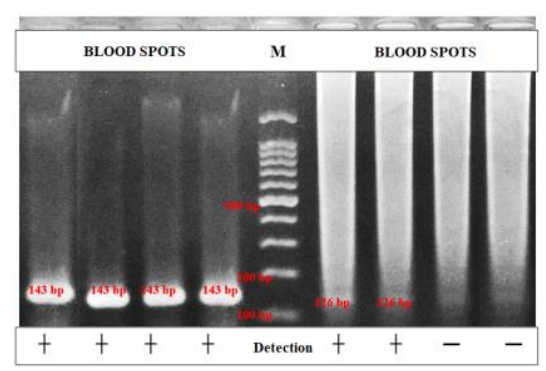

Fig. 1. Results of visualization of PCR results of $143 \mathrm{bp}$ \& 126 bp sample of blood spots, (M) marker.

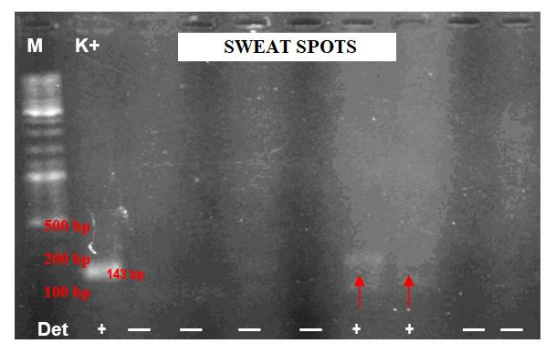

Fig. 2. Result of visualization of $143 \mathrm{bp}$ PCR result sample of sweat spot, (M) marker, K+ (K562). 


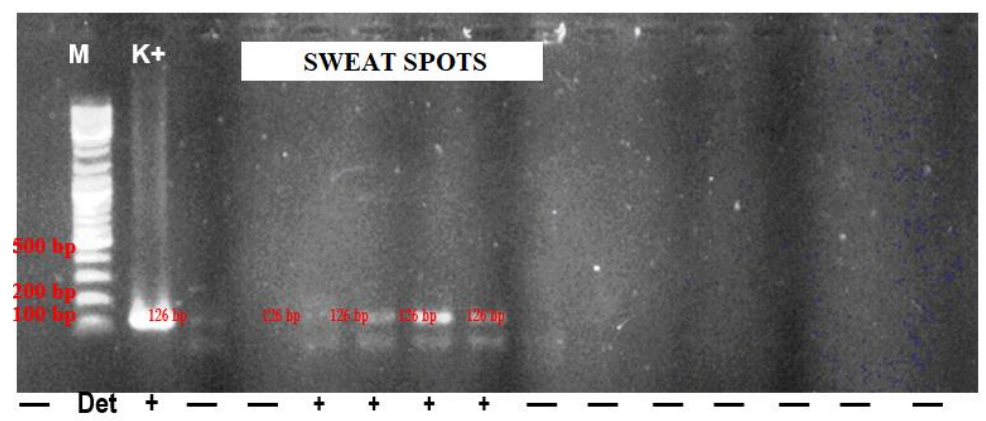

Fig. 3. Results of visualization of 126 bp PCR result sample of sweat spot, (M) marker, K+ (K562).

Table 2. Results of mtDNA detection of blood and sweat spot detection on D-Loop HVS I 143 bp nt: 16268-16410 and D-Loop HVS II 126 bp nt: 34-159

\begin{tabular}{lcccc}
\hline \multirow{2}{*}{ Samples } & \multicolumn{2}{c}{ HVS I 143 bp nt : $16268-16410$} & \multicolumn{2}{c}{ HVS II 126 bp nt : 34 - 159 } \\
\cline { 2 - 5 } Blood spots & Detected & Not detected & Detected & Not detected \\
\cline { 2 - 5 } Sweat spots & $23(95.83 \%)$ & $1(04.17 \%)$ & $22(91.87 \%)$ & $2(08.13 \%)$ \\
\hline
\end{tabular}

Table 2 shows the results of mitochondrial DNA detection of blood and sweat spots through D-Loop HVS I 143 bp nt: 16268-16410 and D-Loop HVS II 126 bp nt: 34-159. The sample of blood spot on D-Loop HVS I 143 bp nt: 16268-16410 and D-Loop HVS II 126bp nt: $34-159$ are above $90 \%$. Whereas, the detected sample of sweat spots was only $5 \%-20 \%$.

\section{Sample DNA sequencing}

Several samples still showing positive detected results [+] were examined by sequencing analysis. The mitochondrial DNA area of D-loop HVS I 143 bp nt: 1626816410 and D-Loop HVS II 126bp nt: $34-159$ from the sample of blood spots and sweat spots were analyzed by Dideoksi Sanger method as follows.

1st_BASE_2345711_20_143_143.ab1 for blood spot sample

NNNNNNNNGGNNNNNNNNNNNNNNANNNNGC

ATNAACCGNCAGAGCACATTAGGGGCAGACCA NNCTCGCCGCNGNANACGGGNCNCCCGGGGAG ACCAAAGNANCCCGNCGAGCCGGCANCTGNTG AGTCACGACCCGAGAGGNGTGACGNCAGCCTG GGN

> 1st_BASE_397247_mtDNA_126bp1.ab1 for blood spot sample

GTNGNNNTNNNNNNNNNNNNNNNNGTCCCCCG GCGCGCCCCCCTCAAGNNNNNNCTACTNGNCCT GAATTNATTACNGCCNCCTNNTCNCNTGANTNC TGCTNCNNNANGNNNNNGTANNNNNNNNACGN NNNNGNNNNNGTNNANNNNNNNNNNNNN

\section{NNNNNNCNTAGTCANNNGATNGNTNCTACNNN} ATNNNN

1st_BASE_2345711_20_143_143.ab1 for sweat spot sample

NNNNNNNNGGNNNNNNNNNNNNNNANNNNGC ATNAACCGNCAGAGCACATTAGGGGCAGACCA NNCTCGCCGCNGNANNNNNNNNNNNNNNNNA GACCAAAGNANCCCGNCGAGCCGGCANCTGNT GAGTCACGACCCGAGAGGNGTGACGNCAGCCT GGGN

> 1st_BASE_397247_mtDNA_126bp1.ab1 for sweat spot sample

GTNGNNNTNNNNTNCTCCTTNGNNGTCCCCCGG CGCGCCCCCCTCAAGNNNNNNCTACTNGNCCTN NNNNNNNNNNNCCTNNTCNCNTGANTNCTGCT NCNNNANGNNNNNGTANNNNNNNNNACGNNN NNNNGTNNANANNNNNNNNNNNNN NNNNNNCNTAGTCANNNGATNGNTNCTACNNN ATNNNN

DNA from blood and sweat spots of mtDNA amplicon product $126 \mathrm{bp}$ and $143 \mathrm{bp}$ indicated nucleotide damage characterized by the letter ' $\mathrm{N}$ '.

\section{DISCUSSION}

In this study, the DNA levels of blood and sweat spots were still in the minimum range of DNA for DNA examination. However, this is not the only major factor that determines the success of amplification in the field 
of forensic DNA, since the DNA content used is often found in small amount. Although DNA level from sweat spots was relatively low, the DNA within remained well-protected, which was marked by succesful DNA profiling from the mitochondrial DNA amplification in D-loop area with amplification product of $143 \mathrm{bp}$. The integrity or intactness of the DNA in forensic medicine is more important than the DNA levels.

According to Melton (2003), there are two possible causes why target DNA cannot be used as a DNA template. First, the inadequate levels of the DNA. Second, the DNA levels are sufficient, but it has been degraded into smaller sections lower than $250 \mathrm{bp}$ in the area to be duplicated, so the primer cannot stick to it. In addition to the DNA level, sufficient quality of the DNA is also needed which must meet the minimal degraded conditions (Butler 2003). If the degradation of the DNA is severe, the primer may not be attached to the target DNA to be duplicated (Muladno 2002).

Failure of DNA detection on DNA testing by PCR method is caused by, for example, the small amount of target DNA, damage, insufficient DNA polymerase, insufficient PCR cycles, and PCR inhibitor. PCR-based method is known as a high sensitive instrument to use for DNA amplification, especially in forensic DNA typing, in which the DNA is often found in relatively small amounts. Similarly, the possibility of inadequate DNA polymerase and PCR cycles used and the presence of PCR inhibitors have been anticipated through the PCR optimization process.

DNA damage itself can be divided into 2 main types: endogenous damage, such as damage caused by reactive oxygen species due to oxidative phosphorylation process; and exogenous damage, such as ultraviolet radiation (UV 200-300 $\mathrm{nm}$ ) from the sun or radiation from other sources, such as X-rays and gamma rays and thermal disruption. DNA damage in forensic material itself starts from the time when an individual dies due to endogeneous factors, or more popularly known as postmortem DNA damage (Hofreiter et al 2001). The occurrence of DNA damage is along with the autolysis, several hours or days after death (Burger et al 1999). Post-mortem DNA damage may be in the form of modified pyrimidine, baseless sites, intermolecular crosslinks, and low molecular weight of the DNA due to strand breakage (Hofreiter et al 2001).

This post-mortem DNA damage, of course, has an effect on the overall post-mortem DNA, which includes DNA fragmentation that reduces the success of PCR amplification caused by low DNA levels (low molecular weight DNA). This degraded or fragmented DNA profile, when examined using electrophoresis, shows faint or even nonexistent profile of DNA bands (Promega 2001), or, when using genescan, usually appears as a phenomenon called "allelic drop out" and "stutter band" (Burger et al 1999).

Damage to DNA will worsen along with the increasing age of individual deaths, in which the DNA in the body experiences more extensive fragmentation due to autolysis, bacterial degradation, and spontaneous depuration (Gollenberg et al 1996, Burger et al 1999). These chemical reactions cause the DNA to undergo further oxidation and hydrolysis. Oxidative damage causes DNA to lose its nitrogenous bases. Whereas, the hydrolytic damage itself causes deamination, depuration and depyrimidation of DNA bases, which in turn leads to shortening of DNA fragments due to the cleavage of the posphate bond or phosphate link, or in other words known as DNA fragmentation (Burger et al 1999). Similarly, samples attached to the victim's body, like blood and sweat spots, will also experience the process of cell or DNA damage.

In this study, blood samples were obtained from blood and sweat spots on D-Loop HVS II of 126 bp (nt 34159) and D-Loop HVS I 143 bp (nt 16268-16410). Some samples were detected positively (blood spots $>95 \%$ and 5\%-20\% sweat spots). This was reflected from the results of electrophoresis, showing positive results detected on amplicon product of $143 \mathrm{bp}$ and 126bp. Analysis of mitochondrial DNA using a mini primer that has been used to support nuclear DNA examination shows that mitochondrial DNA has high detection power. This is evidenced by the results of examination on mitochondrial DNA, using mtDNA primer of D-Loop HVS II 126 bp (nt 59-134) and D-Loop HVS I 143 bp (nt 16268-16410). These primers belong to mini primer with short amplicon product under 200 bp (Gabriel 2001, Butler 2003). Positive detection results in blood spotting and sweat spotting samples is obtained as mitochondrial DNA has the ability to reliably test the DNA (Gabriel et al 1999). It is suggested that mitochondrial DNA has a higher number of copies compared to nuclear DNA. This is in line with the opinion of Kline et al (2005) who stated that mitochondrial DNA regions of HV1 (nt 16024-16365) and HV2 (nt 73-340) is particularly useful for forensic mitochondrial DNA analysis, when there is a problem of nuclear DNA conditions because of limited number and damaged nuclear DNA (highly degraded DNA).

\section{CONCLUSION}

Mini primers of mitochondrial DNA in mtDNA amplification product of D-Loop HVS II 126 bp (nt 34-159) and D-Loop HVS I 143 bp (nt 16268-16410) are effect- 
ively used as a support for DNA profiling in forensic medicine.

\section{REFERENCES}

Alice RI, Jodi MM (1999). Mitochondrial DNA analysis at the FBI laboratory. Forensic Science Communication 1

Anderson S, Bankier AT, Nierlich DP, Roe BA, Sanger F, Schreier PH, Smith AJH, Staden R, Young IG (1981). Sequence and organization of the human mitochondrial genome. Nature 290, 457-465

Atmaja DS (2005). Peranan sidik jari DNA pada bidang kedokteran forensic; Materi Workshop DNA fingerprinting. Yogyakarta, Universitas Gadjah Mada

Butler JM, Yin S, Bruce RM (2004). The development of reduced size STR amplicons as tools for analysis of degraded DNA. National Institute of Standards and Technology

Edward M, Golenberg, Ann B, Paul W (1996). Effect of highly fragmented DNA on PCR. Nucleic Acids Research 24

Gabriel MN, Huffine EF, Ryan JH (2001). Improved mtDNA sequence analysis of forensic remains using a "mini-primer" set amplification strategy. J Forensic Sci 46, 247

Innis MA, Gelfand DH (1990). Optimization of PCRs. In: PCR Protocols (Innis, Gelfand, Sninsky and White, eds.). New York, Academic Press, p 3-12

Lusida MI, Handajani R, Purwanta M (1999). DNA sequencing. In: Biologi Molekuler Kedokteran (Putra, ST.(Ed)). Surabaya, Airlangga University Press, p 136-149

Muladno (2002). Seputar teknologi rekayasa genetika, Bogor, Pustaka Wirausaha Muda

Robin ED, Wong R (1988). Mitochondrial DNA molecules and number of mitochondria per cell in mamillian cells. J Cellular Physiology 136, 507-13

Saiki RK (1985). The design and optimization of the PCR. In: PCR technology principles and applications for DNA amplification (Erlich HA ed). New York, Stocton Press

Sudoyo H (2003). DNA sebagai marka antropologi dan kedokteran forensik. Kumpulan Makalah Mitochondrial Medicine. Malang, Unibraw

Sullivan KM, Hopgood R, Gill P (1992). Identification of human remains by amplification and automated sequencing of mitochondrial DNA. Int J Legal Med $105,83-6$ 